\title{
Large-Scale Data Integration Reveals Colocalization of Gene Functional Groups with Meta-QTL for Multiple Disease Resistance in Barley
}

\author{
Patrick Schweizer and Nils Stein \\ Leibniz-Institut für Pflanzengenetik und Kulturpflanzenforschung (IPK), Corrensstrasse 3, D-06466 Gatersleben, Germany \\ Submitted 4 May 2011. Accepted 5 July 2011.
}

\begin{abstract}
Race-nonspecific and durable resistance of plant genotypes to major pathogens is highly relevant for yield stability and sustainable crop production but difficult to handle in practice due to its polygenic inheritance by quantitative trait loci (QTL). As far as the underlying genes are concerned, very little is currently known in the most important crop plants such as the cereals. Here, we integrated publicly available data for barley (Hordeum vulgare subsp. vulgare) in order to detect the most important genomic regions for QTL-mediated resistance to a number of fungal pathogens and localize specific functional groups of genes within these regions. This identified 20 meta-QTL, including eight hot spots for resistance to multiple diseases that were distributed over all chromosomes. At least one meta-QTL region for resistance to the powdery mildew fungus Blumeria graminis was found to be co-linear between barley and wheat, suggesting partial evolutionary conservation. Large-scale genetic mapping revealed that functional groups of barley genes involved in secretory processes and cell-wall reinforcement were significantly over-represented within QTL for resistance to powdery mildew. Overall, the results demonstrate added value resulting from large-scale genetic and genomic data integration and may inform genomic-selection procedures for race-nonspecific and durable disease resistance in barley.
\end{abstract}

Race-nonspecific disease resistance (NR) of plants, also referred to as quantitative or basal resistance, is defined as conferring incomplete protection against many races of a given pathogen species, often being expressed in adult plants only (so-called "adult plant resistance") (St Clair 2010). This trait has long been identified as a highly relevant research and breeding objective for increasing yield stability and sustainability of crop production because of its durability under field conditions. Indeed, several loci for NR have been found to remain effective after years or decades of use (Brueggeman et al. 2008; Fukuoka et al. 2009; Kou and Wang 2010; Krattinger et al. 2009; Song et al. 1995; Stuthman 2002). Another important feature of NR is its broad effectiveness. NR protects against many races of a given pathogen. These two features set NR clearly apart from race-specific resistance that relies on recognition of usually not more than one effector gene product, his-

Corresponding author: P. Schweizer; Telephone: +49-39482-5660; Fax: +49-39482-5692; E-mail: schweiz@ipk-gatersleben.de

* The $\boldsymbol{e}$-Xtra logo stands for "electronic extra" and indicates that five supplementary tables and three supplementary figures are published online. torically referred to as an avirulence (Avr) factor, of a particular pathogen race by one resistance $(\mathrm{R})$ protein of the nucleotide-binding leucine-rich repeat (NB-LRR) type encoded by a single dominant $R$ gene (Meyers et al. 2003). The major limitation of race-specific resistance is its lack of durability: $R$ genes are often rapidly overcome by new races carrying mutated or deleted corresponding Avr genes. Even if a given effector $(A v r)$ gene is completely lost, this usually does not cause a detectable reduction of virulence due to a considerable degree of functional redundancy of pathogens effector sets. The breakdown of $R$ gene efficacy leads to the so-called "boom and bust cycles" of plant-pathogen interactions under field conditions (McDonald and Linde 2002). From an application-oriented point of view, the main problem of exploiting NR lies in its polygenic nature. It is usually inherited as several quantitative trait loci (QTL) and, thus, strongly depends on genotypeenvironment interaction. It has become clear in recent years that map positions of QTL for resistance to different diseases can largely vary, and targeted approaches to introgress QTL for resistance to multiple diseases have not yet been undertaken. As a prerequisite toward this goal, knowledge about genomic regions harboring multiple disease resistance needs to be generated, and markers tightly linked to these QTL need to be developed. Ideally, markers would be located within the genes underlying any given QTL, provided that these have been identified by map-based cloning or candidate-gene approaches. At present, the mechanism of NR is far from being understood because only a few genes mediating this trait have been isolated. NR may be a manifestation of pathogen-associated molecular pattern (PAMP)-triggered immunity representing the most ancient form of plant innate immunity and protecting plants broadly against many races of a given pathogen (Jones and Dangl 2006). NR protects different host genotypes to different extents against a given pathogen race, which probably reflects differential sensitivity of effector targets to effectormediated undermining of PAMP-triggered immunity or differential PAMP-triggered "defense potential" in the (theoretical) absence of effectors.

Barley is a major crop that benefits from vigorous research programs for a better understanding of the genetic and genomic setup of different traits, including stress resistance (Brueggeman et al. 2002; Douchkov et al. 2005; Komatsuda et al. 2007; Ramsay et al. 2011; Seeholzer et al. 2010; Sutton et al. 2007). Resulting from these efforts, valuable tools and resources such as well-characterized experimental populations and large collections of natural genetic variability (Rostoks et al. 2006; Waugh et al. 2009), high-density genetic maps (Aghnoum et al. 2010; Close et al. 2009; Sato et al. 2009; Stein et al. 2007), a physical genome map (Schulte et al. 2009), and extensive 
gene-expression data (Druka et al. 2010; Wise et al. 2007) have been made publicly available. However, most datasets coexist separately. In order to generate added value, it would be required to cross-reference common denominators and efficiently integrate such datasets. As far as NR of barley to major fungal diseases is concerned, QTL have been described in a number of biparental mapping populations with a genetic resolution between approximately 1 and $10 \mathrm{cM}$ (Aghnoum et al. 2010; Bilgic et al. 2005; Chen et al. 2003; Marcel et al. 2007; Steffenson et al. 1996), which is sufficient for a search of genomic hot spots for NR to different fungal diseases. Moreover, recent progress in the genetic mapping of thousands of genebased markers in the barley genome either by direct mapping in segregating populations (Close et al. 2009; Potokina et al. 2008; Stein et al. 2007) or via synteny-based predictions (Mayer et al. 2011) has made it possible to integrate genebased data such as functional protein prediction or transcript regulation with meta-QTL information. Two additional data sources were used for this purpose: the MapMan-based functional classification scheme of barley unigenes represented on the Barley1 transcript profiling chip of Affymetrix (Sreenivasulu et al. 2008) and transcript-profiling data from barley-powdery mildew interactions (Zellerhoff et al. 2010).

A recent search for colocalization of a limited number of defense-related candidate genes of barley, for which we have obtained functional genomics data (transient induced gene silencing [iTIGS]), resulted in the identification of a first set of QTL colocalizing genes (Aghnoum et al. 2010). Here, we extended this approach to genome-wide scale and report on the integration of a publicly available, large-scale dataset of barley in order to detect important genomic regions for NR and localize specific groups of genes within these regions. This allowed us to raise hypotheses about important gene groups for NR and represents a step toward genomic selection of race-nonspecific and durable resistance to major pathogens.

\section{RESULTS}

Meta-QTL for NR.

QTL data of resistance to fungal diseases attacking barley leaves has been collected in barley since 1992, when molecular markers became available for the genetic mapping of specific traits (Table 1; Supplementary Table S1). After excluding a number of studies or individual QTL due to incomplete information for meta-QTL analysis or QTL-confidence intervals exceeding 30 centimorgans (cM), a total of 166 QTL from 28 studies remained in the analysis. Several colocalizing QTL against a specific pathogen were derived from the same experimental population used in different studies and, thus, cannot be considered completely independent. However, in none of these partly redundant cases were identical fungal races and plant growth stages used, which were found to largely affect the efficiency of individual resistance QTL (L. J. Wang et al. 2010). Therefore, such QTL "duplicates" were not eliminated from the meta analysis. For a direct comparison of all barleypathogen interaction QTL positions included in this study, we projected the corresponding flanking or peak markers onto the high-density consensus map "Barley, integrated, Marcel 2009" (deposited in Graingenes 2.0 database and referred to as QTL map throughout) containing 6,986 markers. A considerable number of QTL against the barley powdery mildew fungus Blumeria graminis f. sp. hordei had already been projected previously to this map based on direct QTL mapping in the contributing five barley populations (Aghnoum et al. 2010).

Table 1. Quantitative trait loci (QTL) studies used for the meta-QTL analysis

\begin{tabular}{|c|c|c|}
\hline Pathogens & Parents of mapping populations ${ }^{a}$ & Reference \\
\hline Blumeria graminis & $\begin{array}{l}\text { Steptoe }(\text { R_S }) \times \operatorname{Morex}(\text { R_S }) ; \operatorname{Rec}(\mathrm{R}) \times \operatorname{Dom}(\mathrm{S}) ; \text { Tremois }(\mathrm{R}) \times \operatorname{Nure}(\mathrm{S}) \\
\text { L94 }(\mathrm{R}) \times \operatorname{Vada}(\mathrm{S}) ; \operatorname{SusPtrit}(\mathrm{R}) \times \operatorname{Vada}(\mathrm{S}) ; \operatorname{Cebada} \operatorname{Capa}\left(\mathrm{R} \_S\right) \times \operatorname{SusPtrit}\left(\mathrm{R} \_S\right)\end{array}$ & Aghnoum et al. 2010 \\
\hline B. graminis & $\operatorname{Danilo}(\mathrm{R}) \times \operatorname{Igri}(\mathrm{S})$ & Backes et al. 1996 \\
\hline B. graminis & $\mathrm{IB} 87(\mathrm{R}) \times \operatorname{Vada}(\mathrm{S})$ & Backes et al. 2003 \\
\hline B. graminis & TR306(R) $\times$ Harrington $(\mathrm{S})$ & Falak et al. 1999 \\
\hline B. graminis & Proctor(R1) $\times$ Nudinka(R2) & Heun, 1992 \\
\hline B. graminis & PI282605(R) $\times$ Tiffany $(S)$ & Repkova et al. 2009 \\
\hline B. graminis & SBCC97(R) $\times$ Plaisant $(S)$ & Silvar et al. 2010 \\
\hline \multicolumn{3}{|l|}{ B. graminis; B. sorokiniana; } \\
\hline Pyrenophora teres & OUH602(R) × Harrington $(\mathrm{S})$ & Yun et al. 2005 \\
\hline B. graminis; Puccinia hordei & ISR42-8(R) $\times$ Scarlett $(S)$ & Schmalenbach et al. 2008 \\
\hline \multicolumn{3}{|l|}{ B. graminis; $P$. hordei; } \\
\hline Rhynchosporium commune & ISR42-8(R) × Scarlett $(S)$ & von Korff et al. 2005 \\
\hline B. graminis; $R$. commune & L94(R) $\times \operatorname{Vada}(S)$ & Shtaya et al. 2006 \\
\hline B. sorokiniana & $\begin{array}{l}\text { ND11231-12(R) } \times \text { VB9524(S); TR251(R) } \times \text { Gairdner }(S) \\
\text { WPG8412-9-2-1(R) } \times \text { Lindwall }(\mathrm{S})\end{array}$ & Bovill et al. 2010 \\
\hline B. sorokiniana & Wild barley collection(R_S) & Roy et al. 2010 \\
\hline Magnaporthe oryzae & TR306(R) $\times$ Harrington $(\bar{S})$ & Chen et al. 2003 \\
\hline M. oryzae & Baronesse $(\mathrm{R}) \times$ BCD47(S) & Kongprakhon et al. 2009 \\
\hline M. oryzae & TR306(R) × Harrington $(S)$ & Sato et al. 2001 \\
\hline P. hordei & $\begin{array}{l}\text { Steptoe }(\mathrm{R} 1) \times \operatorname{Morex}(\mathrm{R} 2) ; \operatorname{Dom}(\mathrm{R}) \times \operatorname{Rec}(\mathrm{S} .) ; \operatorname{Vada}(\mathrm{R}) \times \mathrm{L} 94(\mathrm{~S}) \\
\operatorname{Vada}(\mathrm{R}) \times \operatorname{SusPtrit}(\mathrm{S}) ; \operatorname{Cebada} \operatorname{Capa}(\mathrm{R}) \times \operatorname{SusPtrit}(\mathrm{S})\end{array}$ & Marcel et al. 2007 \\
\hline Pyrenophora teres & $\begin{array}{l}\operatorname{Morex}(\mathrm{R}) \times \operatorname{Steptoe}(\mathrm{S}) \text {; Morex }(\mathrm{R}) \times \operatorname{Diktoo}(\mathrm{S}) ; \operatorname{Morex}(\mathrm{R}) \times \operatorname{Harrington}(\mathrm{S}) \\
\text { TR306 }(\mathrm{R}) \times \operatorname{Harrington}(\mathrm{S})\end{array}$ & Bilgic et al. 2005 \\
\hline P. teres & TR251 (R) $\times$ CDC Dolly $(\mathrm{S})$ & Grewal et al. 2008 \\
\hline P. teres & Pompadour $(\mathrm{R}) \times \operatorname{Stirling}(\mathrm{S})$ & Gupta et al. 2010 \\
\hline P. teres & Chevron $(\mathrm{R}) \times \operatorname{Stander}(\mathrm{S})$ & Ma et al. 2004 \\
\hline P. teres & CI 9819(R) $\times$ Rolfi(S) & Manninen et al. 2006 \\
\hline P. teres & M120(R) × Sep2-72(S) & Pierre et al. 2010 \\
\hline P. teres; B. sorokiniana & Steptoe(R_S) $\times$ Morex(R_S $)$ & Steffenson et al. 1996 \\
\hline R. commune (R. secalis) & Abyssinian_CI668(R) $\times$ Ingrid $(\mathrm{S})$ & Gronnerod et al. 2002 \\
\hline R. commune ( $R$. secalis) & Alexis(S1) $\times$ Regatta(S2) & Jensen et al. 2002 \\
\hline R. commune (R. secalis) & Tadmor(R) $\times$ WI2291(S) & Sayed et al. 2004 \\
\hline R. commune (R. secalis) & Triton $(\mathrm{R}) \times \operatorname{Igri}(\mathrm{S})$ & Wagner et al. 2008 \\
\hline
\end{tabular}

${ }^{a} \mathrm{R}$, resistant parent; $S$, susceptible parent; R_S, no clear difference between parents. 
The projected QTL were then combined into meta-QTL as recently described (Liu et al. 2009). In addition, regions composed of six or more overlapping QTL were analyzed for the presence of more than one meta-QTL (Fig. 1, indicated by meta-QTL number plus $\mathrm{A}, \mathrm{B}$, or $\mathrm{C}$ ) using a simple and robust procedure, as described below and in Supplementary Figure $\mathrm{S} 1$. The procedure for multiple meta-QTL detection was compared with a maximum likelihood method introduced by Goffinet and Gerber (2000) and used, for example, by Loffler and associates (2009) for meta-QTL data of wheat resistance to Fusarium head blight. Our approach detected four of the five previously described meta-QTL (Loffler et al. 2009). The putative meta-QTL not identified by our approach was represented by only two overlapping individual QTL and, thus, did not fulfill our minimum selection criteria ( $\geq 3$ QTL). In total, 20 meta-QTL for disease resistance were found to be distributed over all seven barley chromosomes. Eight of them (numbers $1,3,4,7 \mathrm{~B}, 9,10 \mathrm{~A}, 16$, and 17) appeared to be resistance hot spots against several diseases. Although some meta-QTL affected multiple fungi with biotrophic, hemibiotrophic, or necrotrophic life style, others (such as numbers 4, 6, 11, 13, and 18) were exclusively or predominantly effective against the obligate biotrophic pathogens B. graminis f. sp. hordei and the barley rust fungus Puccinia hordei. On the other hand, meta-QTL numbers 7C, 16, and 17B were mostly effective against hemibiotrophic or necrotrophic fungi such as Rhynchosporium commune (formerly R. secalis) or Pyrenophora teres.

The largest number of resistance QTL has been identified in the barley-B. graminis f. sp. hordei interaction. Therefore, we focused on this disease and compared the approximate positions of meta-QTL between barley and hexaploid wheat, which represents a closely related species of the Triticeae tribe of cereals (Supplementary Table S2). Between the two species, very few conserved orthologous markers have been used for QTL mapping. Thus, to be able to compare barley and wheat genetic positions, we calculated the positions of QTL peak or flanking markers in wheat relative to the length of the genetic maps of the linkage groups wherein the QTL were mapped and aligned these relative positions to the genetic map of the corresponding barley chromosomes. This approximate approach assumes the absence of strong distortions of genetic map positions of syntenic markers between wheat A, B, and D homologous chromosomes and also between corresponding wheat and barley chromosomes. The distribution patterns of QTL for $B$. graminis resistance were not largely overlapping between the two species (Fig. 2). However, at least three genomic regions on chromosomes $1 \mathrm{~A} / \mathrm{B} / \mathrm{D} / \mathrm{H}, 2 \mathrm{~A} / \mathrm{B} / \mathrm{D} / \mathrm{H}$, and $4 \mathrm{~A} / \mathrm{B} / \mathrm{D} / \mathrm{H}$ could be identified harboring at least three QTL in each of the two species. Due to the two well-established translocations between distal parts of wheat chromosome arm 4AL with parts of 5AL and 7BS, two of the wheat QTL should actually be compared with QTL positions on barley chromosomes 5HL and 7HS, respectively (Fig. 2, highlighted by arrows). However, these corrections neither created new colocalizing metaQTL in the two species nor did they destroy the observed colocalization on $4 \mathrm{~A} / \mathrm{B} / \mathrm{D} / \mathrm{H}$.

\section{QTL colocalization of functional gene groups.}

A number of plant multigene families or pathways have been identified or proposed to play crucial roles during plantpathogen interactions. Among those are, for example, proteins belonging to the receptor-like kinase (RLK) superfamily, the RING-E3 ubiquitin ligase family, or genes involved in cellwall lignification (Bhuiyan et al. 2009; Krupa et al. 2006; Zeng et al. 2006). Informed from these data, we chose a set of multigene families or cellular pathways by using the binning system of MapMan and tested the positions of the corresponding genes with those of meta-QTL for resistance to $B$. graminis. Map positions of QTL and most of the genes were based on the QTL map and Barley OPA123-2008, consensus", deposited in Graingenes 2.0 and referred to as BOPA map, respectively. In addition to directly mapped genes, we used

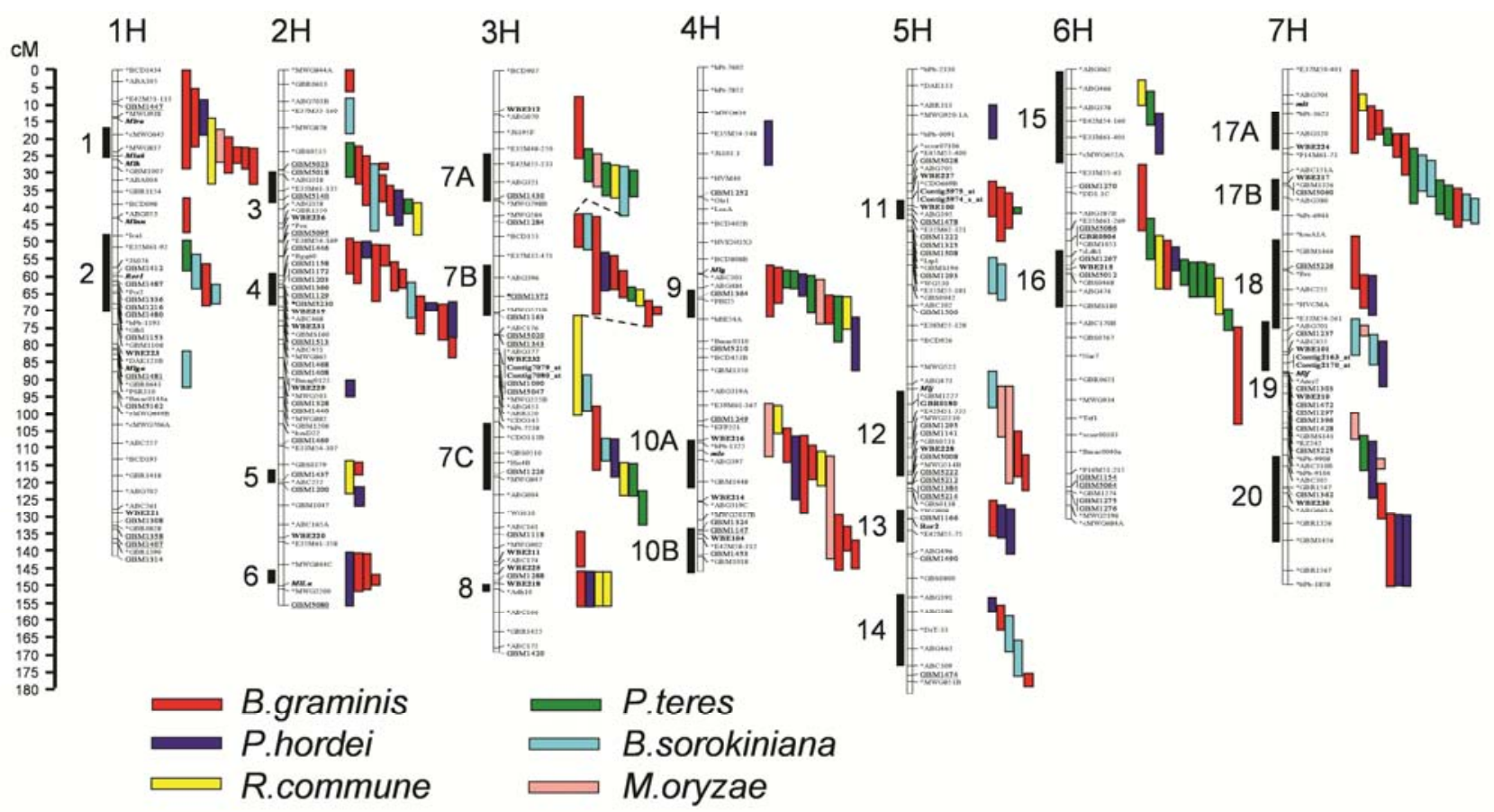

Fig. 1. Meta-quantitative trait loci (QTL) for resistance of barley to major fungal pathogens. QTL positions projected onto the "Barley, integrated, Marcel 2009" are indicated by colored bars to the right of the respective chromosomes. They either span the distance between nearby QTL-flanking markers or indicate peak-marker positions ( \pm 5 centimorgans $[\mathrm{cM}]$ ). QTL extending over more than $30 \mathrm{cM}$ were excluded from the analysis. Meta-QTL calculated from midpoint positions of overlapping QTL are indicated by black bars to the left of chromosomes. Meta-QTL numbers followed by letters indicate the presence of several neighboring meta-QTL located within more complex QTL regions. 
information derived from synteny-based in silico prediction of gene order in barley (Mayer et al. 2009, 2011). However, out of a total of 21,766 genes mapped based on grass synteny, only those 11,014 barley genes associated with a unigene ID in the U35 assembly of the HarvEST database plus a probe-set ID on the Barley1 chip of Affymetrix (Close et al. 2004) were taken into account. In general, data from direct mapping, including expression QTL (eQTL), were preferred, resulting in a total of 4,859 genes with synteny-based, predicted map position. The accuracy of prediction of map positions was verified by using 518 genes mapped as eQTL or transcript-derived marker (TDM), which were not represented by BOPA map markers providing the framework for the in silico mapping (Potokina et al. 2008). We found that $93.7 \%$ of the 518 verified genes were predicted to the correct chromosome, with a median offset between predicted and actual map positions of $6.006 \mathrm{cM}$. This median offset also includes differences between map positions of the single Steptoe $\times$ Morex versus the consensus BOPA map and, thus, represents a maximum error estimation. The result suggests that the in silico mapping approach based on threeway syntenic relationships between barley and related grass species indeed provides robust predictions of the real map positions in barley (Mayer et al. 2011). In order to enhance the accuracy of gene-QTL colocalization, we performed an offset correction between BOPA and QTL maps based on linear regression of 376 common single-nucleotide protein (SNP) markers. This led to an observed remaining offset of $<5 \mathrm{cM}$ for 97\% of the common markers (Supplementary Fig. S2).

For the gene-QTL colocalization study, we tested whether a gene was mapping inside genome regions that are spanned by at least three overlapping resistance QTL to $B$. graminis $\mathrm{f}$. $\mathrm{sp}$. hordei (Fig. 2). Gene members of the selected multigene families "class III peroxidases" and "RLK" as well as the cellular process "vesicle transport" were found to be significantly overrepresented in the genome fraction covered by resistance QTL to B. graminis f. sp. hordei (Fig. 3). On the other hand, two gene categories selected as negative controls ("histones" and "development") were represented according to the null hypothesis (occurrence inside resistance QTL equal to the relative length of the genetic map occupied by the projection of all these QTL). Genes encoding NB-LRR-type proteins, WRKY transcription factors, and lignifying enzymes might also be enriched inside resistance QTL but will not be discussed fur-

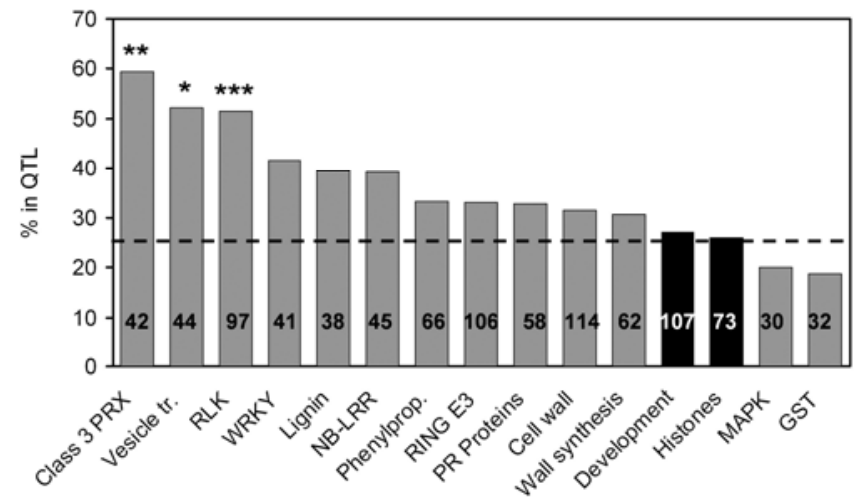

Fig. 3. Co-localization of functional groups of barley genes with quantitative trait loci (QTL) for resistance to Blumeria graminis f. sp. hordei. Functional gene groups were formed based on the MapMan binning system and tested for over-representation inside resistance QTL by $\chi^{2}$ analysis. The dotted line represents the value of the null hypothesis. Black columns indicate gene groups selected as negative control because they are not expected to be strongly involved in plant defense. Numbers inside columns indicate the number of genes per group; *,**, and *** indicate $P<$ $0.05,0.005$, and 0.0005 , respectively. PRX, peroxidase; tr, transport; RLK, receptor-like protein kinase; WRKY, WRKY transcription factor; Phenylprop., phenylpropanoid pathway; RING-E3, "really-interesting-newgene"-type E3 ubiquitin ligase; PR, pathogenesis-related; MAPK, mitogenassociated protein kinase; GST, glutathione- $S$-transferase.

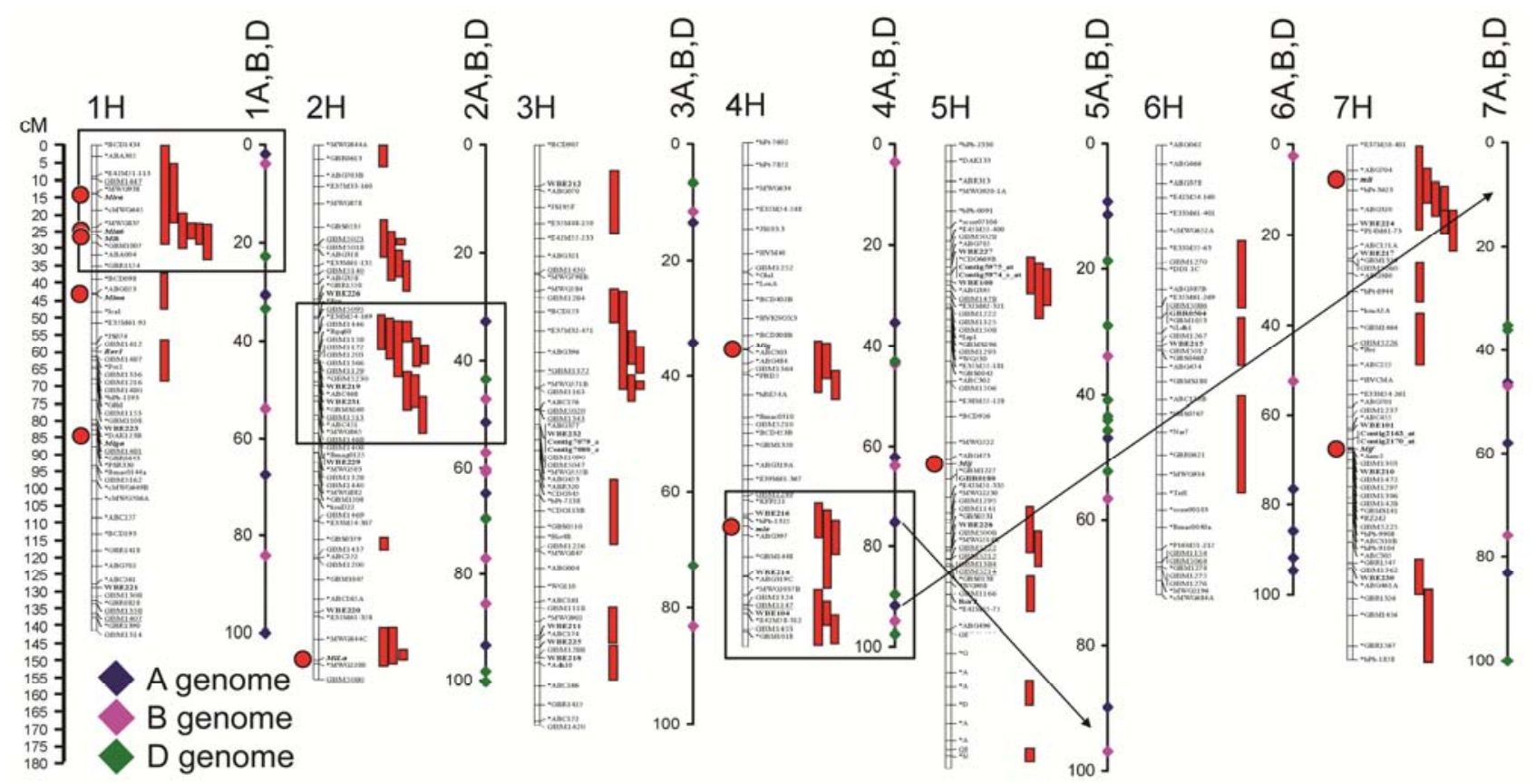

Fig. 2. Meta-quantitative trait loci (QTL) for resistance of barley and wheat to Blumeria graminis. QTL positions projected onto the "Barley, integrated, Marcel 2009" of barley are indicated by bars. They either span the distance between nearby QTL flanking markers or indicate peak marker positions ( \pm 5 centimorgans $[\mathrm{cM}])$. QTL extending over more than $30 \mathrm{cM}$ were excluded from the analysis. QTL on wheat chromosomes are shown as colored diamonds and indicate either midpoints between flanking markers or peak-marker positions. Wheat QTL positions are shown in percentage of the map length of the corresponding homologous group of chromosomes. Two arrows indicate initial, syntenic positions of two wheat QTL on chromosome 4AL, which are affected by two major, interchromosomal wheat translocations (Miftahudin et al. 2004). Three regions of overlapping meta-QTL are highlighted by frames. Positions of major resistance genes are indicated by red circles. 
ther because the signals were statistically not significant. One possible source of false-positive results might be uneven gene density among chromosomes, especially if QTL regions would turn out to be generally enriched in genes. Although the gene density of barley is still not known at a genome-wide scale, a first estimation based on BAC-end sequencing and the physical mapping of chromosome $3 \mathrm{~B}$ of the closely related hexaploid wheat revealed a trend for enhanced gene density in distal regions of chromosome arms, compared with the centromeric region (Choulet et al. 2010). Therefore we tested whether class III peroxidases, RLK, or vesicle-transport genes mapped preferably to distal chromosome regions, which might have created a false-positive signal together with resistance QTL also located distally. No preferred clustering of these three gene groups in distal regions were observed compared with the two

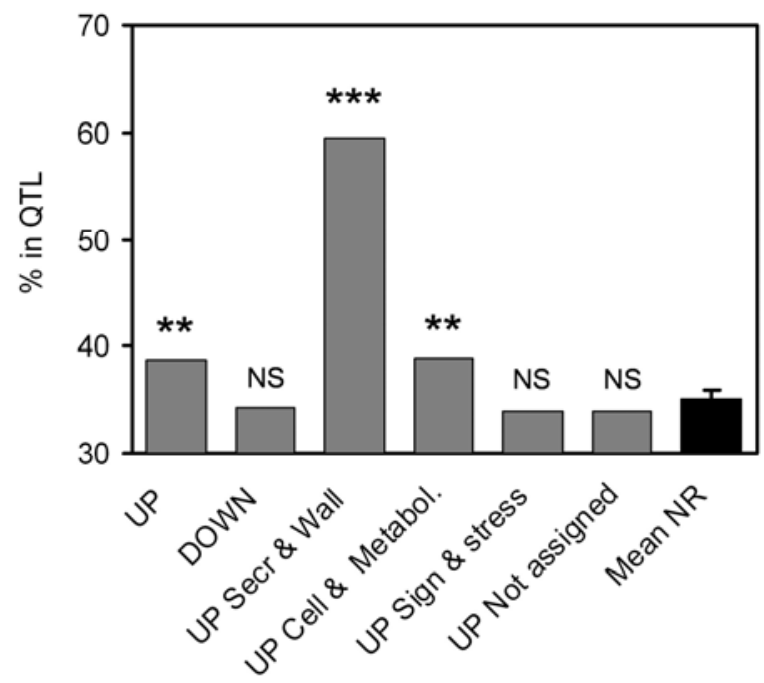

Fig. 4. Co-localization of pathogen-regulated genes with resistance quantitative trait loci (QTL) to Blumeria graminis f. sp. hordei. Functional groups of genes regulated in B. graminis f. sp. hordei-attacked barley leaf epidermis were formed based on the MapMan binning system and tested for over-representation inside resistance QTL. A one-sample $t$ test against the mean of 10 random samples of nonregulated genes was performed for this purpose; $* *$ and $* * *$ indicate $P<0.005$ and 0.0005 , respectively; NS, not significant; NR, not regulated; Secr., secretion; Sign., signaling. negative control groups "development" and "histones" plus the nonsignificant group "cell wall" (Supplementary Fig. S3). This strongly suggests that the over-representation of the former three functional gene groups within NR QTL was not due to enhanced proximal-distal gene-density gradients.

\section{Regulated candidate genes.}

Barley responds to attack by $B$. graminis with the up- or downregulation of a large number of transcripts (Wise et al. 2007; Zellerhoff et al. 2010; Zierold et al. 2005). In total, 468 significantly upregulated and 349 downregulated transcripts previously identified in epidermal peels of powdery-mildewattacked barley were used as the initial data set for a QTL colocalization analysis of the encoding genes with powdery mildew meta-QTL, as described above (Zellerhoff et al. 2010). Out of 817 regulated transcripts, 248 upregulated and 184 downregulated ones could be assigned genetic map positions of the corresponding genes plus a MapMan functional classification. Unlike the colocalization analysis performed for functional groups of genes regardless of their regulation behavior, the genes represented on the barley-PGRC1 transcript-profiling array showed a bias for colocalization inside QTL regions, for unknown reasons. Therefore, instead of performing $\chi^{2}$ analysis against the null-hypothetical value of $24 \%$ colocalizing genes (discussed above) we compared, by $t$ test, the extent of QTL colocalization with the mean of 10 random samples containing 250 nonregulated genes each, which are represented on the array. On average, $35.1 \%$ of the control group of nonregulated genes showed QTL colocalization whereas $38.7 \%$ of the entire group of upregulated genes located inside resistance QTL (Fig. 4). This weak but significant over-representation suggested that one or a few functional groups among the upregulated genes might be involved in generating the detected positive signal. To test this possibility, the upregulated transcripts were subdivided into combined MapMan bins that, together, contained at least 30 genes with genetic map positions (Supplementary Table S5). This revealed a strong and extremely significant over-representation of upregulated genes belonging to the combined functional category "secretion and cell wall", and a weak but also significant over-representation of the combined bins belonging to "metabolism". The upregulated secretion- and cell-wall-related genes were analyzed individually (Table 2). Approximately $50 \%$ of all identified candi-

Table 2. Over-representation of secretion- and cell-wall-related genes with upregulated transcripts within quantitative trait loci (QTL) for resistance to Blumeria graminis f. sp. hordei

\begin{tabular}{|c|c|c|c|c|c|}
\hline Clone ID $^{\mathrm{a}}$ & BlastX & $E$ value & MapMan BIN (abbreviated BIN name) & Chromosome & $\mathbf{c M}^{\mathbf{c}}$ \\
\hline HO03K07 & $\beta$-Galactosidase & $7 E-68$ & Cell wall degradation mann-xyl-ara-fuc & $5 \mathrm{H}$ & 52.3 \\
\hline HO15K 13 & GDP-mannose 4.6 dehydratase & $6 \mathrm{E}-19$ & Cell wall precursor synthesis GMD & $7 \mathrm{H}$ & 25.9 \\
\hline HH01А03 & UDP-glucose dehydrogenase & $1 \mathrm{E}-120$ & Cell wall precursor synthesis UGD & $4 \mathrm{H}$ & 48.7 \\
\hline HU02C15 & Clathrin heavy chain & $4 \mathrm{E}-90$ & Cell vesicle transport & $5 \mathrm{H}$ & 56.8 \\
\hline HO12F09 & HvSNAP34 & $3 \mathrm{E}-45$ & Cell vesicle transport & $7 \mathrm{H}$ & 8.2 \\
\hline HV03K 15 & Peroxidase & $1 \mathrm{E}-113$ & Miscellaneous peroxidases & $2 \mathrm{H}$ & 37.3 \\
\hline HW03O08 & Peroxidase & $2 \mathrm{E}-81$ & Miscellaneous peroxidases & $2 \mathrm{H}$ & 151.2 \\
\hline HW07H16 & Peroxidase & $1 \mathrm{E}-75$ & Miscellaneous peroxidases & $2 \mathrm{H}$ & 151.2 \\
\hline HD01A02 & Peroxidase & $1 \mathrm{E}-106$ & Miscellaneous peroxidases & $2 \mathrm{H}$ & 156.7 \\
\hline HW09H06 & Peroxidase & $8 \mathrm{E}-46$ & Miscellaneous peroxidases & $3 \mathrm{H}$ & 71.1 \\
\hline HO13D15 & Peroxidase & $3 \mathrm{E}-48$ & Miscellaneous peroxidases & $3 \mathrm{H}$ & 71.1 \\
\hline HW08M02 & Sec13 transport protein & $1 \mathrm{E}-113$ & Protein targeting secretory pathway PM & $3 \mathrm{H}$ & 50.2 \\
\hline HM01K22 & Sec61 transport protein & $4 \mathrm{E}-15$ & Protein targeting secretory pathway unspecified & $3 \mathrm{H}$ & 56.4 \\
\hline HA11A22 & N-Hydroxycinnamoyl/benzoyl transferase & $1 \mathrm{E}-64$ & Secondary metabol phenylprop lignin biosynth HCT & $2 \mathrm{H}$ & 73.8 \\
\hline $\mathrm{HO} 15 \mathrm{O} 04$ & Phenylalanine ammonia-lyase & $1 \mathrm{E}-127$ & Secondary metabol phenylprop lignin biosynth PAL & $2 \mathrm{H}$ & 62.7 \\
\hline $\mathrm{HO} 2 \mathrm{~F} 16$ & Phenylalanine ammonia-lyase & $1 \mathrm{E}-121$ & Secondary metabol phenylprop lignin biosynth PAL & $2 \mathrm{H}$ & 77.1 \\
\hline HO04F05 & Phenylalanine ammonia-lyase & $1 \mathrm{E}-120$ & Secondary metabol phenylprop lignin biosynth PAL & $2 \mathrm{H}$ & 79.2 \\
\hline HM02L09 & Phenylalanine ammonia-lyase & $1 \mathrm{E}-120$ & Secondary metabol phenylprop lignin biosynth PAL & $2 \mathrm{H}$ & 79.2 \\
\hline НX03М03 & ABC Transporter-like & $1 \mathrm{E}-126$ & Transport ABC transporters and MDR systems & $4 \mathrm{H}$ & 48.7 \\
\hline
\end{tabular}

\footnotetext{
${ }^{a}$ Expressed sequence tag clone identity.

b PM, plasma membrane; MDR, multiple drug resistance; HCT, hydroxycinnamoyl/benzoyl transferase; PAL, phenylalanine ammonia lyase.

${ }^{c}$ Cumulative genetic distance in centimorgans (cM) from the telomere of the short chromosome arm.
} 
date genes were found to encode either i) phenylalanine ammonia-lyase, catalyzing the first committed step of the phenylpropanoid pathway, which leads to-among otherslignin precursors; or ii) secreted class III peroxidase isoforms, known to be involved in cross-linking of lignin precursors as well as in the generation of reactive oxygen species. Therefore, pathogen-induced cell-wall lignification probably plays an important role in NR of barley in accordance with first functional data obtained in the wheat-powdery mildew interaction employing transient gene silencing (Bhuiyan et al. 2009). The importance of cell-wall modifications upon powdery mildew attack is further substantiated by the QTL-colocalizing genes encoding $\beta$-galactosidase, GDP-mannose 4,6 dehydratase, and UDP-glucose dehydrogenase (Table 2).

Several of the upregulated genes of combined bins "cell and metabolism" that were also significantly more abundant inside resistance QTL encode proteins of amino acid biosynthesis and lipid metabolism (Table 3). Several amino acid biosynthetic proteins are implicated in tryptophan biosynthesis, which was identified previously as probably important in barley for defense-related signaling or synthesis of antifungal compounds (Bednarek et al. 2009).

The fact that downregulated genes were not associated with resistance QTL to $B$. graminis suggests that these regulation events reflect reorientation of the cell from "resting state" to stress metabolism (e.g., in order to save energy) rather than a direct involvement of the corresponding proteins (e.g., as effector targets) in plant-pathogen interactions.

\section{DISCUSSION}

The integration of large-scale datasets bears the potential to uncover meta-trends and correlations that help to describe biological systems more accurately and formulate hypotheses about mechanisms underlying specific traits more precisely.
Here, we integrated genetic and genomic data of barley in order to gain information of the genetic architecture of racenonspecific and durable disease resistance and of gene functional groups potentially relevant for the trait. This guided us toward PAMP recognition, secretory pathways, and cell-wall modifications as being important for NR. The datasets that were combined comprised i) meta-QTL for resistance to most important barley fungal diseases projected onto a recently developed high-density consensus map of 6,986 genetic markers, ii) genetic map positions of 11,014 genes by direct mapping or by grass synteny-based prediction of gene order, iii) handcurated functional classification by the MapMan binning system of 12,015 barley genes represented by the Barley 1 chip of Affymetrix, and iv) transcript-profiling data of 10,297 genes from epidermal peels of powdery-mildew-attacked leaves.

Despite the complexity of the genetic setup of NR in barley, reflected by a considerable number of QTL, eight loci distributed over all chromosomes except $5 \mathrm{H}$ appeared to be hot spots for multiple disease resistance. Thus, the development and use of molecular (gene-based) markers for the introgression of these QTL may be an efficient way to improve broadly acting resistance, provided that the same genes are underlying metaQTL against several diseases for at least some of these loci. The comparison of chromosome regions of meta-QTL against powdery mildew in barley and wheat showed more differences than overlap, indicating either a rather low degree of functional conservation of underlying genes or a high degree of nonsyntenic positions of such resistance-related genes as a result of small-scale genomic rearrangements ("reshuffling") of both genomes (Fig. 2). However, one region of clear overlap of meta-QTL across species was found in the subtelomeric region of the long arm of chromosomes $4 \mathrm{H}$ and $4 \mathrm{~A}$, and $4 \mathrm{~B}$ and $4 \mathrm{D}$, respectively. In barley, this region contains a cluster of germinlike proteins of group $4(H v G E R 4 a-h)$ that were long identified as potentially important for resistance to this fungus in

Table 3. Over-representation of metabolic genes with upregulated transcripts within quantitative trait loci (QTL) for resistance to Blumeria graminis f. sp. hordei

\begin{tabular}{|c|c|c|c|c|c|}
\hline Clone ID a $^{a}$ & BlastX & $E$ value & MapMan BIN (abbreviated BIN name) ${ }^{b}$ & Chromosome & $\mathbf{c M}^{\mathbf{c}}$ \\
\hline HY05G15 & $\begin{array}{l}\text { Phospho-2-dehydro-3-deoxyheptonate } \\
\text { aldolase }\end{array}$ & $1 \mathrm{E}-114$ & AA metabol synthesis aromatic AA chorismate & $2 \mathrm{H}$ & 55.0 \\
\hline HY07P02 & Anthranilate synthase & $1 \mathrm{E}-106$ & AA metabol synthesis aromatic AA tryptophan & $4 \mathrm{H}$ & 59.4 \\
\hline HO02G11 & Phosphoribosylanthranilate transferase & $2 \mathrm{E}-48$ & AA metabol synthesis aromatic AA tryptophan & $4 \mathrm{H}$ & 103.1 \\
\hline HP01N05 & Glutamate carboxylase & $3 \mathrm{E}-47$ & AA metabol synthesis GABA & $4 \mathrm{H}$ & 33.4 \\
\hline HD01B02 & ATP phosphoribosyl transferase & $2 \mathrm{E}-73$ & AA metabol synthesis histidine & $4 \mathrm{H}$ & 96.6 \\
\hline HW03I02 & Pyruvate decarboxylase & $6 \mathrm{E}-49$ & Fermentation PDC & $3 \mathrm{H}$ & 44.8 \\
\hline HU02E16 & Acyl-[acyl-carrier-protein] desaturase & $6 \mathrm{E}-89$ & Lipid metabol FA synthesis and FA elongation & $2 \mathrm{H}$ & 59.2 \\
\hline HD02K 23 & $\begin{array}{l}\text { Acyl:coa ligase acetate-coa synthetase- } \\
\text { like }\end{array}$ & $2 \mathrm{E}-12$ & Lipid metabol FA synthesis and FA elongation & $2 \mathrm{H}$ & 149.6 \\
\hline HW05D03 & Lipase class 3-like & $5 \mathrm{E}-87$ & Lipid metabol lipid degradation lipases & $3 \mathrm{H}$ & 53.0 \\
\hline HW09G14 & Cell wall invertase & $1 \mathrm{E}-71$ & Major $\mathrm{CHO}$ metabol degradation sucrose invertases cell wall & $4 \mathrm{H}$ & 114.7 \\
\hline HW05F18 & Invertase & $3 \mathrm{E}-83$ & Major CHO metabol degradation sucrose invertases neutral & $4 \mathrm{H}$ & 48.7 \\
\hline HW08G11 & Aldose 1-epimerase & $2 \mathrm{E}-66$ & Minor CHO metabol others & $2 \mathrm{H}$ & 66.8 \\
\hline HS01N18 & Cytochrome c oxidase & $2 \mathrm{E}-46$ & Mitochondrial electron transport / ATP synthesis & $2 \mathrm{H}$ & 55.0 \\
\hline HO15B24 & NADH-dependent glutamate synthase & $3 \mathrm{E}-60$ & $\mathrm{~N}$-metabol ammonia metabol & $3 \mathrm{H}$ & 54.5 \\
\hline HU01C13 & $\begin{array}{l}\text { Cytosolic 6-phosphogluconate } \\
\text { dehydrogenase }\end{array}$ & $2 \mathrm{E}-68$ & OPP oxidative PP & $7 \mathrm{H}$ & 4.9 \\
\hline HU04D06 & Glucose-6-phosphate dehydrogenase & $5 \mathrm{E}-82$ & OPP oxidative PP & $2 \mathrm{H}$ & 70.5 \\
\hline HY05H08 & Ribosomal protein L30 & $8 \mathrm{E}-54$ & Protein synthesis miscellaneous ribosomal protein & $3 \mathrm{H}$ & 55.6 \\
\hline HG01M07 & Chloroplast pigment-binding protein & & & & \\
\hline & $\mathrm{CP} 24$ & $2 \mathrm{E}-61$ & PS light reaction photosystem II & $2 \mathrm{H}$ & 66.1 \\
\hline HO15F23 & Flavanone 3-hydroxylase & $1 \mathrm{E}-56$ & Secondary metabol flavonoids dihydroflavonols & $4 \mathrm{H}$ & 111.7 \\
\hline HV03D24 & $\begin{array}{l}\text { Hydroxymethylglutaryl coenzyme A } \\
\text { synthase }\end{array}$ & $7 \mathrm{E}-60$ & Secondary metabo & $4 \mathrm{H}$ & 108.8 \\
\hline HV03J13 & NADP-dependent malic enzyme & $1 \mathrm{E}-100$ & TCA/org transformation other organic acid transformations & $3 \mathrm{H}$ & 47.1 \\
\hline
\end{tabular}

${ }^{a}$ Expressed sequence tag clone identity.

b AA, amino acid; GABA, gamma amino butyric acid; PDC, pyruvate decarboxylase; FA, fatty acid; CHO, carbohydrate; OPP, oxidative pentose phosphate; PS, photosynthesis.

${ }^{\mathrm{c}}$ Cumulative genetic distance in centimorgans $(\mathrm{cM})$ from the telomere of the short chromosome arm. 
both wheat and barley, based on functional genomic data (Schweizer et al. 1999; Zimmermann et al. 2006). In rice, a similar cluster of gene orthologs of $H v G E R 4$ at the collinear position on rice chromosome 8 was proposed to be responsible for a major resistance QTL against the rice blast fungus (Manosalva et al. 2009). In accordance with the rice results, a QTL for rice blast resistance was also colocalizing with the HvGER4 cluster of barley. Together, these data put forward GER4-type proteins and the encoding gene loci as important for resistance to several diseases in all three grass species. The proteins encoded by the $H v G E R 4$ tandem gene duplicates were found to be under strong purifying selection (Himmelbach et al. 2010), which suggests that gene-copy number variation or promoter polymorphisms may cause allelic diversity at this locus.

NR to pathogens may be a manifestation of PAMP-triggered immunity (Jones and Dangl 2006). This ancient type of immunity is triggered by the perception of PAMPs via RLK proteins such as the flagellin receptor FLS22 (Chinchilla et al. 2007). Signals are transduced by mitogen-activated protein-kinase cascades resulting in the activation of WRKY transcription factors that induce the expression of defense-related proteins for prepenetration resistance, primarily based on the generation of an antimicrobial apoplastic environment and cell-wall re-enforcement (Collinge 2009; Panstruga et al. 2009). Our data-integration approach provided statistical evidence for the relevance of different components of PAMP-triggered immunity in NR to $B$. graminis f. sp. hordei: Receptor-like protein kinases, factors of vesicle transport, and secreted class III peroxidases were found to be significantly more abundant within regions of meta-QTL for resistance to this pathogen than expected by chance. All three gene functional groups have been proposed to be components of PAMP-triggered immunity and accordingly, NR (Johrde and Schweizer 2008; Schweizer 2008; C. F. Wang et al. 2010; Zipfel 2009). In a previous candidate-gene study, peroxidases have also been found to cooccupy recombination bins more abundantly with QTL for resistance to barley leaf rust than expected by chance (Gonzalez et al. 2010).

On the other hand, mapped race-specific $R$ genes and NBLRR-type genes did not show a significant trend for colocalization with resistance QTL, suggesting that NR of barley to $B$. graminis f. sp. hordei is not caused by one or several weakly acting or partially defeated $R$ genes, as has been discussed, for example, in the rice-Magnaporthe oryzae interaction (Ballini et al. 2008). In principle, the scenario of $R$-gene-based NR would also appear plausible, assuming that involved $R$ genes recognize one or several widespread and rather conserved effectors from a given pathogen species or forma specialis. The different observation made in the abovementioned meta-QTL study in rice could be explained by plant-pathogen interactionspecific differences in the involvement of weakly acting NBLRR-type R proteins in NR.

Some functional groups such as phenylpropanoid-pathway enzymes or pathogenesis-related proteins were not associated significantly with resistance meta-QTL, although the genes have been described as relevant for plant-pathogen interactions (van Loon et al. 2006). This might be explained by only relatively few members of the encoding gene families being actually involved in defense. It is generally accepted that genes whose transcripts show regulation under changing physiological conditions may be more relevant for adaptation of the organism to these conditions. Therefore, we took not only functional classification but also gene regulation in powderymildew-attacked epidermis into account. We focused on transcript-profiling data from peeled epidermis because response of this tissue decides the success or failure of pathogen ingress and initial haustorium formation. Among the upregulated genes, we found a strong enrichment of candidates belonging to the combined functional bins "secretion and cell wall" inside resistance QTL. Thus, the identified 19 genes would allow the development of SNP markers to search for significant alleletrait associations in diverse barley collections, in order to further substantiate their hypothetical role in NR. Associated haplotypes could subsequently be used for introgression into susceptible elite material in prebreeding approaches, especially after directly assessing gene function by transient or stable gene silencing during the interaction with powdery mildew.

The biological importance of the second set of QTL colocalizing candidate genes belonging to "cell and metabolism" is currently less clear. However, in this group, several promising candidates also were identified belonging to the shikimate- and tryptophan-biosynthetic pathway, recently identified to be important for durable resistance (Bednarek et al. 2009; Hu et al. 2009; Ishihara et al. 2008; Sanchez-Vallet et al. 2010). Rather unexpectedly, the upregulated group of genes belonging to "signaling and stress" was not enriched inside resistance QTL. Therefore, it may be speculated that a majority of these genes are more indirectly involved in biotic stress responses and, rather, reflect attempts of the host to adjust to the new physiological situation.

In summary, we present converging evidence for an important role of genes involved in PAMP perception, protein- or metabolite secretion, and cell-wall modification, including lignification, for race-nonspecific and durable resistance of barley to $B$. graminis. The same gene sets might also be important for more broadly acting resistance because many robust metaQTL acting against $B$. graminis are nested with QTL for resistance to other major fungal pathogens. Therefore, we propose the systematic population of such QTL hot spots with genebased markers, together with high-throughput functional assays such as transient interference RNA by TIGS or virus-induced gene silencing (Douchkov et al. 2005; Holzberg et al. 2002; Ihlow et al. 2008), as a promising approach toward the identification of causative genes for durable resistance. More advanced examples of candidate genes such as GER4 in barley, wheat, and rice (Himmelbach et al. 2010; Manosalva et al. 2008; Schweizer et al. 1999) suggest that this approach will ultimately be successful.

\section{MATERIALS AND METHODS}

\section{Meta-QTL analysis.}

Resistance QTL against foliar diseases described in barley over the past 19 years have been projected onto the map "Barley, Integrated, Marcel 2009" with 6,986 genetic markers (Aghnoum et al. 2010) by using either QTL peak- or flankingmarker positions specified by the authors of the QTL studies. If only peak-marker positions were available, the QTL region was assumed by default to extend $\pm 5 \mathrm{cM}$ north and south from peak-marker position, resulting in a confidence interval of 10 $\mathrm{cM}$. This default confidence interval is similar to the average observed interval of $12.9 \mathrm{cM}$ of the remaining projected QTL analyzed here. If only one flanking marker could be projected onto the consensus map, a QTL interval of $10 \mathrm{cM}$ extension north or south from the lower or upper flanking marker, respectively, was assumed by default. If neither peak nor flanking markers were included in the consensus map, nearby tightly linked markers (maximum of $5 \mathrm{cM}$ from the peak or flanking markers) were searched in the Graingenes 2.0 database. If no replacement markers could be identified within this distance, the QTL was excluded from the analysis. Meta-QTL were defined as regions covered by overlapping QTL, and their $95 \%$ confidence interval was calculated from midpoint 
positions of the overlapping QTL. In order to detect overlapping QTL regions that contained more than one (possibly overlapping) meta-QTL, a simple procedure was applied based on two assumptions: First, the observed overlapping QTL are a normally distributed, random sample representing the truly underlying meta-QTL; second, QTL of more complex meta-QTL regions should form several clusters, resulting in uneven distances between individual QTL. Therefore, QTL distances larger than the $95 \%$ confidence interval of the corresponding distance distribution were taken as indicators of regions lying between neighboring meta-QTL. In order to enhance the stringency of this approach, two potentially clustered subregions of at least three QTL had to be separated by at least two pairs of QTL with significantly enlarged map distance.

QTL for resistance to powdery mildew in wheat described since 1999 were used for approximate comparison with corresponding barley QTL in order to identify common meta-QTL against the same pathogen in the two species. Due to the scarcity of conserved ortholog wheat markers used in these studies and very uneven length of the homologous wheat chromosome maps, the position relative to the map length of each wheat chromosome was calculated and adjusted to scale with the more precise barley consensus map.

\section{QTL colocalization of barley genes.}

Map positions of genes were obtained by direct mapping or by synteny-based predictions and correspond to positions in the "Barley, OPA123-2008, Consensus" map with 2,943 genetically mapped SNP markers (Close et al. 2009). In the case of synteny-based map positions, a virtual order of barley genes was constructed based on the syntenic relationship between barley and reference genome sequences of Oryza sativa, Brachpodium distachyon, and Sorghum bicolor and anchored to the barley genetic map by syntenic BOPA markers (Mayer et al. 2009, 2011). For the comparison of gene and QTL map positions, an offset correction between the QTL map and the gene map (BOPA map was performed based on linear regression of 376 common markers. For approximately $14 \%$ of the genes, map positions of TDM (Potokina et al. 2008) as well as markers derived from eQTL mapping were used. eQTL with a $\log$ of the likelihood ratio score higher than 20 were considered as being in cis (i.e., colocalizing with the transcript-encoding gene) (Potokina et al. 2008). TDM and eQTL marker positions were found to be highly co-linear with the BOPA map, with a median offset between common markers of 7.24 cM. Therefore, no additional offset correction was performed for these gene positions.

\section{Functional gene categorization.}

The MapMan binning system was used for functional gene categorization in barley (Sreenivasulu et al. 2008). Two hierarchical levels of binning were used: for categorization of all genetically mapped genes one level below superbins (e.g., "light reaction" in superbin "photosynthesis, PS") whereas, for categorization of genes regulated in pathogen-attacked epidermis, combinations of terminal sub-bins such as "cell wall precursor synthesis GMD" related to secretory processes and cell-wall metabolism were combined. Details of all categorized genes of this study are given in Supplementary Tables S3 and S4. In the case of NB-LRR-type $R$ genes, we added hand-curated members to the MapMan binning file, which otherwise would have yielded only 17 genes within bin "stress biotic". This was achieved by the keyword-based query ("LRR" NOT "receptor" NOT "kinase") of descriptions of unigenes in HarvEST assembly number 35 of barley. All members of bin "miscellaneous, peroxidase" are annotated as class III, or contain a predicted $\mathrm{N}$-terminal secretion signal, or both.

\section{ACKNOWLEDGMENTS}

This work was supported by the Leibniz Institute of Plant Genetics and Crop Plant Research (to P. Schweizer) and by the German Federal Ministry of Education and Research (BMBF, project Barlex 0314000) (to N. Stein).

\section{LITERATURE CITED}

Aghnoum, R., Marcel, T. C., Johrde, A., Pecchioni, N., Schweizer, P., and Niks, R. E. 2010. Basal host resistance of barley to powdery mildew: Connecting quantitative trait loci and candidate genes. Mol. Plant-Microbe Interact. 23:91-102.

Backes, G., Schwarz, G., Wenzel, G., and Jahoor, A. 1996. Comparison between QTL analysis of powdery mildew resistance in barley based on detached primary leaves and on field data. Plant Breed. 115:419-421.

Backes, G., Madsen, L. H., Jaiser, H., Stougaard, J., Herz, M., Mohler, V., and Jahoor, A. 2003. Localisation of genes for resistance to Blumeria graminis f. sp. hordei and Puccinia graminis in a cross between a barley cultivar and a wild barley Hordeum vulgare ssp. spontaneum line. Theor. Appl. Genet. 106:353-362.

Ballini, E., Morel, J. B., Droc, G., Price, A., Courtois, B., Notteghem, J. L., and Tharreau, D. 2008. A genome-wide meta-analysis of rice blast resistance genes and quantitative trait loci provides new insights into partial and complete resistance. Mol. Plant-Microbe Interact. 21:859868.

Bednarek, P., Pislewska-Bednarek, M., Svatos, A., Schneider, B., Doubsky, J., Mansurova, M., Humphry, M., Consonni, C., Panstruga, R., SanchezVallet, A., Molina, A., and Schulze-Lefert, P. 2009. A glucosinolate metabolism pathway in living plant cells mediates broad-spectrum antifungal defense. Science 323:101-106.

Bhuiyan, N. H., Selvaraj, G., Wei, Y. D., and King, J. 2009. Gene expression profiling and silencing reveal that monolignol biosynthesis plays a critical role in penetration defence in wheat against powdery mildew invasion. J. Exp. Bot. 60:509-521.

Bilgic, H., Steffenson, B., and Hayes, P. 2005. Comprehensive genetic analyses reveal differential expression of spot blotch resistance in four populations of barley. Theor. Appl. Genet. 111:1238-1250.

Bovill, J., Lehmensiek, A., Sutherland, M. W., Platz, G. J., Usher, T., Franckowiak, J., and Mace, E. 2010. Mapping spot blotch resistance genes in four barley populations. Mol. Breed. 26:653-666.

Brueggeman, R., Rostoks, N., Kudrna, D., Kilian, A., Han, F., Chen, J., Druka, A., Steffenson, B., and Kleinhofs, A. 2002. The barley stem rust-resistance gene Rpg1 is a novel disease-resistance gene with homology to receptor kinases. Proc. Natl. Acad. Sci. U.S.A.99:9328-9333.

Brueggeman, R., Druka, A., Nirmala, J., Cavileer, T., Drader, T., Rostoks, N., Mirlohi, A., Bennypaul, H., Gill, U., Kudrna, D., Whitelaw, C., Kilian, A., Han, F., Sunl, Y., Gill, K., Steffenson, B., and Kleinhofs, A. 2008. The stem rust resistance gene Rpg5 encodes a protein with nucleotide-binding-site, leucine-rich, and protein kinase domains. Proc. Natl. Acad. Sci. U.S.A.105:14970-14975.

Chen, H., Wang, S. P., Xing, Y. Z., Xu, C. G., Hayes, P. M., and Zhang, Q. F. 2003. Comparative analyses of genomic locations and race specificities of loci for NR to Pyricularia grisea in rice and barley. Proc. Natl. Acad. Sci. U.S.A.100:2544-2549.

Chinchilla, D., Zipfel, C., Robatzek, S., Kemmerling, B., Nurnberger, T., Jones, J. D. G., Felix, G., and Boller, T. 2007. A flagellin-induced complex of the receptor FLS2 and BAK1 initiates plant defence. Nature 448:497-U412.

Choulet, F., Wicker, T., Rustenholz, C., Paux, E., Salse, J., Leroy, P., Schlub, S., Le Paslier, M.C., Magdelenat, G., Gonthier, C., Couloux, A., Budak, H., Breen, J., Pumphrey, M., Liu, S. X., Kong, X. Y., Jia, J. Z., Gut, M., Brunel, D., Anderson, J. A., Gill, B. S., Appels, R., Keller, B., and Feuillet, C. 2010. Megabase level sequencing reveals contrasted organization and evolution patterns of the wheat gene and transposable element spaces. Plant Cell 22:1686-1701.

Close, T. J., Wanamaker, S. I., Caldo, R. A., Turner, S. M., Ashlock, D. A., Dickerson, J. A., Wing, R. A., Muehlbauer, G. J., Kleinhofs, A., and Wise, R. P. 2004. A new resource for cereal genomics: $22 \mathrm{~K}$ barley GeneChip comes of age. Plant Physiol. 134:960-968.

Close, T. J., Bhat, P. R., Lonardi, S., Wu, Y. H., Rostoks, N., Ramsay, L., Druka, A., Stein, N., Svensson, J. T., Wanamaker, S., Bozdag, S., Roose, M. L., Moscou, M. J., Chao, S. A. M., Varshney, R. K., Szucs, P., Sato, K., Hayes, P. M., Matthews, D. E., Kleinhofs, A., Muehlbauer, G. J., DeYoung, J., Marshall, D. F., Madishetty, K., Fenton, R. D., Condamine, P., Graner, A., and Waugh, R. 2009. Development and implementation of high-throughput SNP genotyping in barley. BMC Genomics 10:582.

Collinge, D. B. 2009. Cell wall appositions: The first line of defence. J. 
Exp. Bot. 60:351-352.

Douchkov, D., Nowara, D., Zierold, U., and Schweizer, P. 2005. A highthroughput gene-silencing system for the functional assessment of defense-related genes in barley epidermal cells. Mol. Plant-Microbe Interact. 18:755-761.

Druka, A., Potokina, E., Luo, Z. W., Jiang, N., Chen, X. W., Kearsey, M., and Waugh, R. 2010. Expression quantitative trait loci analysis in plants. Plant Biotechnol. J. 8:10-27.

Falak, I., Falk, D. E., Tinker, N. A., and Mather, D. E. 1999. Resistance to powdery mildew in a doubled haploid barley population and its association with marker loci. Euphytica 107:185-192.

Fukuoka, S., Saka, N., Koga, H., Ono, K., Shimizu, T., Ebana, K., Hayashi, N., Takahashi, A., Hirochika, H., Okuno, K., and Yano, M. 2009. Loss of function of a proline-containing protein confers durable disease resistance in rice. Science 325:998-1001.

Goffinet, B., and Gerber, S. 2000. Quantitative trait loci: A meta-analysis. Genetics 155:463-473.

Gonzalez, A. M., Marcel, T. C., Kohutova, Z., Stam, P., van der Linden, C. G., and Niks, R. E. 2010. Peroxidase profiling reveals genetic linkage between peroxidase gene clusters and basal host and non-host resistance to rusts and mildew in barley. Plos One 5:e10495. Published online.

Grewal, T. S., Rossnagel, B. G., Pozniak, C. J., and Scoles, G. J. 2008 Mapping quantitative trait loci associated with barley net blotch resistance. Theor. Appl. Genet. 116:529-539.

Gronnerod, S., Maroy, A. G., MacKey, J., Tekauz, A., Penner, G. A., and Bjornstad, A. 2002. Genetic analysis of resistance to barley scald Rhynchosporium secalis in the Ethiopian line 'Abyssinian' CI668. Euphytica 126:235-250.

Gupta, S., Li, C. D., Loughman, R., Cakir, M., Platz, G., Westcott, S., Bradley, J., Broughton, S., and Lance, R. 2010. Quantitative trait loci and epistatic interactions in barley conferring resistance to net type net blotch Pyrenophora teres f. teres isolates. Plant Breed. 129:362-368.

Heun, M. 1992. Mapping quantitative powdery mildew resistance of barley using a restriction-fragment-length-polymorphism map. Genome 35:1019-1025.

Himmelbach, A., Liu, L., Zierold, U., Altschmied, L., Maucher, H., Beier, F., Muller, D., Hensel, G., Heise, A., Schutzendubel, A., Kumlehn, J., and Schweizer, P. 2010. Promoters of the barley germin-like GER4 gene cluster enable strong transgene expression in response to pathogen attack. Plant Cell 22:937-952.

Holzberg, S., Brosio, P., Gross, C., and Pogue, G. P. 2002. Barley stripe mosaic virus-induced gene silencing in a monocot plant. Plant $\mathrm{J}$. 30:315-327.

Hu, P. S., Meng, Y., and Wise, R. P. 2009. Functional contribution of chorismate synthase, anthranilate synthase, and chorismate mutase to penetration resistance in barley-powdery mildew interactions. Mol. Plant-Microbe Interact. 22:311-320.

Ihlow, A., Schweizer, P., and Seiffert, U. 2008. A high-throughput screening system for barley/powdery mildew interactions based on automated analysis of light micrographs. BMC Plant Biol. 8:6.

Ishihara, A., Hashimoto, Y., Tanaka, C., Dubouzet, J. G., Nakao, T., Matsuda, F., Nishioka, T., Miyagawa, H., and Wakasa, K. 2008. The tryptophan pathway is involved in the defense responses of rice against pathogenic infection via serotonin production. Plant J. 54:481-495.

Jensen, J., Backes, G., Skinnes, H., and Giese, H. 2002. Quantitative trait loci for scald resistance in barley localized by a non-interval mapping procedure. Plant Breed. 121:124-128.

Johrde, A., and Schweizer, P. 2008. A class III peroxidase specifically expressed in pathogen-attacked barley epidermis contributes to basal resistance. Mol. Plant Pathol. 9:687-696.

Jones, J. D. G., and Dangl, J. L. 2006. The plant immune system. Nature 444:323-329.

Komatsuda, T., Pourkheirandish, M., He, C. F., Azhaguvel, P., Kanamori, H., Perovic, D., Stein, N., Graner, A., Wicker, T., Tagiri, A., Lundqvist, U., Fujimura, T., Matsuoka, M., Matsumoto, T., and Yano, M. 2007. Six-rowed barley originated from a mutation in a homeodomain-leucine zipper I-class homeobox gene. Proc. Natl. Acad. Sci. U.S.A.104:14241429.

Kongprakhon, P., Cuesta-Marcos, A., Hayes, P. M., Richardson, K. L., Sirithunya, P., Sato, K., Steffenson, B., and Toojinda, T. 2009. Validation of rice blast resistance genes in barley using a QTL mapping population and near-isolines. Breed. Sci. 59:341-349.

Kou, Y. J., and Wang, S. P. 2010. Broad-spectrum and durability: Understanding of quantitative disease resistance. Curr. Opin. Plant Biol. 13:181-185.

Krattinger, S. G., Lagudah, E. S., Spielmeyer, W., Singh, R. P., HuertaEspino, J., McFadden, H., Bossolini, E., Selter, L. L., and Keller, B. 2009. A putative ABC transporter confers durable resistance to multiple fungal pathogens in wheat. Science 323:1360-1363.
Krupa, A., Anamika, and Srinivasan, N. 2006. Genome-wide comparative analyses of domain organisation of repertoires of protein kinases of Arabidopsis thaliana and Oryza sativa. Gene 380:1-13.

Liu, S. Y., Hall, M. D., Griffey, C. A., and McKendry, A. L. 2009. Metaanalysis of QTL associated with Fusarium head blight resistance in wheat. Crop. Sci. 49:1955-1968.

Loffler, M., Schon, C. C., and Miedaner, T. 2009. Revealing the genetic architecture of FHB resistance in hexaploid wheat Triticum aestivum $\mathrm{L}$. by QTL meta-analysis. Mol. Breed. 23:473-488.

Ma, Z. Q., Lapitan, N. L. V., and Steffenson, B. 2004. QTL mapping of net blotch resistance genes in a doubled-haploid population of six-rowed barley. Euphytica 137:291-296.

Manninen, O. M., Jalli, M., Kalendar, R., Schulman, A., Afanasenko, O., and Robinson, J. 2006. Mapping of major spot-type and net-type netblotch resistance genes in the Ethiopian barley line $\mathrm{Cl}$ 9819. Genome 49:1564-1571.

Manosalva, P. M., Davidson, R. M., Liu, B., Zhu, X. Y., Hulbert, S. H., Leung, H., and Leach, J. E. 2009. A germin-like protein gene family functions as a complex quantitative trait locus conferring broad-spectrum disease resistance in rice. Plant Physiol. 149:286-296.

Marcel, T. C., Varshney, R. K., Barbieri, M., Jafary, H., de Kock, M. J. D., Graner, A., and Niks, R. E. 2007. A high-density consensus map of barley to compare the distribution of QTLs for partial resistance to Puccinia hordei and of defence gene homologues. Theor. Appl. Genet. 114:487-500

Mayer, K. F. X., Taudien, S., Martis, M., Simkova, H., Suchankova, P., Gundlach, H., Wicker, T., Petzold, A., Felder, M., Steuernagel, B., Scholz, U., Graner, A., Platzer, M., Dolezel, J., and Stein, N. 2009. Gene content and virtual gene order of barley chromosome 1H. Plant Physiol. 151:496-505.

Mayer, K. F. X., Martis, M., Hedley, P., Šimková, H., Liu, H., Morris, J. A., Steuernagel, B., Taudien, S., Roessner, S., Gundlach, H., Kubaláková, M., Suchánková, P., Murat, F., Felder, M., Nussbaumer, T., Graner, A. Salse, J., Endo, T., Sakai, H., Tanaka, T., Itoh, T., Sato, K., Platzer, M., Matsumoto, T., Scholz, U., Doležel, J., Waugh, R., and Stein, N. 2011. Unlocking the barley genome by chromosomal and comparative genomics. Plant Cell. Online publication. doi:10.1105/tpc.110.082537

McDonald, B. A., and Linde, C. 2002. The population genetics of plant pathogens and breeding strategies for durable resistance. Euphytica 124:163-180.

Meyers, B. C., Kozik, A., Griego, A., Kuang, H. H., and Michelmore, R. W. 2003. Genome-wide analysis of NBS-LRR-encoding genes in Arabidopsis. Plant Cell 15:809-834.

Miftahudin, Ross, K., Ma, X. F., Mahmoud, A. A., Layton, J., Milla, M. A. R., Chikmawati, T., Ramalingam, J., Feril, O., Pathan, M. S., Momirovic, G. S., Kim, S., Chema, Y., Fang, P., Haule, L., Struxness, H., Birkes, J., Yaghoubian, C., Skinner, R., McAllister, J., Nguyen, V., Qi, L. L., Echalier, B., Gill, B. S., Linkiewicz, A. M., Dubcovsky, J., Akhunov, E. D., Dvorak, A. J., Dilbirligi, M., Gill, K. S., Peng, J. H., Lapitan, N. L. V., Bermudez-Kandianis, C. E., Sorrells, M. E., Hossain, K. G., Kalavacharla, V., Kianian, S. F., Lazo, G. R., Chao, S., Anderson, O. D., Gonzalez-Hernandez, J., Conley, E. J., Anderson, J. A., Choi, D. W., Fenton, R. D., Close, T. J., McGuire, P. E., Qualset, C. O., Nguyen, H. T., and Gustafson, J. P. 2004. Analysis of expressed sequence tag loci on wheat chromosome group 4. Genetics 168:651663

Panstruga, R., Parker, J. E., and Schulze-Lefert, P. 2009. SnapShot: Plant immune response pathways. Cell 136:978-U976.

Pierre, S. S., Gustus, C., Steffenson, B., Dill-Macky, R., and Smith, K. P. 2010. Mapping net form net blotch and Septoria speckled leaf blotch resistance loci in barley. Phytopathology 100:80-84.

Potokina, E., Druka, A., Luo, Z. W., Wise, R., Waugh, R., and Kearsey, M. 2008. Gene expression quantitative trait locus analysis of 16,000 barley genes reveals a complex pattern of genome-wide transcriptional regulation. Plant J. 53:90-101.

Ramsay, L., Comadran, J., Druka, A., Marshall, D. F., Thomas, W. T. B., Macaulay, M., MacKenzie, K., Simpson, C., Fuller, J., Bonar, N., Hayes, P. M., Lundqvist, U., Franckowiak, J. D., Close, T. J., Muehlbauer, G. J., and Waugh, R. 2011. INTERMEDIUM-C, a modifier of lateral spikelet fertility in barley, is an ortholog of the maize domestication gene TEOSINTE BRANCHED 1. Nat. Genet. 43:169U125.

Repkova, J., Teturova, K., Dreiseitl, A., and Soldanova, M. 2009. Characterization and chromosomal location of powdery mildew resistance genes from wild barley PI282605. J. Plant. Dis. Prot. 116:257-259.

Rostoks, N., Ramsay, L., MacKenzie, K., Cardle, L., Bhat, P. R., Roose, M. L., Svensson, J. T., Stein, N., Varshney, R. K., Marshall, D. F., Grainer, A., Close, T. J., and Waugh, R. 2006. Recent history of artificial outcrossing facilitates whole-genome association mapping in elite inbred crop varieties. Proc. Natl. Acad. Sci. U.S.A.103:18656-18661. 
Roy, J. K., Smith, K. P., Muehlbauer, G. J., Chao, S. M., Close, T. J., and Steffenson, B. J. 2010. Association mapping of spot blotch resistance in wild barley. Mol. Breed. 26:243-256.

Sanchez-Vallet, A., Ramos, B., Bednarek, P., Lopez, G., PislewskaBednarek, M., Schulze-Lefert, P., and Molina, A. 2010. Tryptophan-derived secondary metabolites in Arabidopsis thaliana confer non-host resistance to necrotrophic Plectosphaerella cucumerina fungi. Plant J. 63:115-127.

Sato, K., Inukai, T., and Hayes, P. M. 2001. QTL analysis of resistance to the rice blast pathogen in barley Hordeum vulgare. Theor. Appl. Genet. 102:916-920.

Sato, K., Nankaku, N., and Takeda, K. A. 2009. high-density transcript linkage map of barley derived from a single population. Heredity 103:110-117

Sayed, H., Backes, G., Kayyal, H., Yahyaoui, A., Ceccarelli, S., Grando, S., Jahoor, A., and Baum, M. 2004. New molecular markers linked to qualitative and quantitative powdery mildew and scald resistance genes in barley for dry areas. Euphytica 135:225-228.

Schmalenbach, I., Korber, N., and Pillen, K. 2008. Selecting a set of wild barley introgression lines and verification of QTL effects for resistance to powdery mildew and leaf rust. Theor. Appl. Genet. 117:1093-1106.

Schulte, D., Close, T. J., Graner, A., Langridge, P., Matsumoto, T. Muehlbauer, G., Sato, K., Schulman, A. H., Waugh, R., Wise, R. P., and Stein, N. 2009. The International Barley Sequencing Consortium-at the threshold of efficient access to the barley genome. Plant Physiol. 149:142-147.

Schweizer, P. 2008. Tissue-specific expression of a defence-related peroxidase in transgenic wheat potentiates cell death in pathogen-attacked leaf epidermis. Mol. Plant Pathol. 9:45-57.

Schweizer, P., Christoffel, A., and Dudler, R. 1999. Transient expression of members of the germin-like gene family in epidermal cells of wheat confers disease resistance. Plant J. 20:541-552.

Seeholzer, S., Tsuchimatsu, T., Jordan, T., Bieri, S., Pajonk, S., Yang, W. X., Jahoor, A., Shimizu, K. K., Keller, B., and Schulze-Lefert, P. 2010. Diversity at the Mla powdery mildew resistance locus from cultivated barley reveals sites of positive selection. Mol. Plant-Microbe Interact. 23:497-509.

Shtaya, M. J. Y., Marcel, T. C., Sillero, J. C., Niks, R. E., and Rubiales, D. 2006. Identification of QTLs for powdery mildew and scald resistance in barley. Euphytica 151:421-429.

Silvar, C., Dhif, H., Igartua, E., Kopahnke, D., Gracia, M. P., Lasa, J. M., Ordon, F., and Casas, A. M. 2010. Identification of quantitative trait loci for resistance to powdery mildew in a Spanish barley landrace. Mol. Breed. 25:581-592.

Song, W. Y., Wang, G. L., Chen, L. L., Kim, H. S., Pi, L. Y., Holsten, T., Gardner, J., Wang, B., Zhai, W. X., Zhu, L. H., Fauquet, C., and Ronald, P. 1995. A receptor kinase-like protein encoded by the rice disease resistance gene, Xa21. Science 270:1804-1806.

Sreenivasulu, N., Usadel, B., Winter, A., Radchuk, V., Scholz, U., Stein, N., Weschke, W., Strickert, M., Close, T. J., Stitt, M., Graner, A., and Wobus, U. 2008. Barley grain maturation and germination: Metabolic pathway and regulatory network commonalities and differences highlighted by new MapMan/PageMan profiling tools. Plant Physiol. 146:1738-1758.

St Clair, D. A. 2010. Quantitative disease resistance and NR loci in breeding. Annu. Rev. Phytopathol. 48:247-268.

Steffenson, B. J., Hayes, P. M., and Kleinhofs, A. 1996 . Genetics of seedling and adult plant resistance to net blotch Pyrenophora teres f. teres and spot blotch Cochliobolus sativus in barley. Theor. Appl. Genet. 92:552-558.

Stein, N., Prasad, M., Scholz, U., Thiel, T., Zhang, H. N., Wolf, M., Kota,
R., Varshney, R. K., Perovic, D., Grosse, I., and Graner, A. 2007. A 1,000-loci transcript map of the barley genome: New anchoring points for integrative grass genomics. Theor. Appl. Genet. 114:823-839.

Stuthman, D. D. 2002. Contribution of durable disease resistance to sustainable agriculture. Euphytica 124:253-258.

Sutton, T., Baumann, U., Hayes, J., Collins, N. C., Shi, B. J., Schnurbusch T., Hay, A., Mayo, G., Pallotta, M., Tester, M., and Langridge, P. 2007. Boron-toxicity tolerance in barley arising from efflux transporter amplification. Science 318:1446-1449.

van Loon, L. C., Rep, M., and Pieterse, C. M. J. 2006. Significance of inducible defense-related proteins in infected plants. Annu. Rev. Phytopathol. 44:135-162.

von Korff, M., Wang, H., Leon, J., and Pillen, K. 2005. AB-QTL analysis in spring barley. I. Detection of resistance genes against powdery mildew, leaf rust and scald introgressed from wild barley. Theor. Appl. Genet. 111:583-590.

Wagner, C., Schweizer, G., Kramer, M., Dehmer-Badani, A., Ordon, F., and Friedt, W. 2008. The complex quantitative barley-Rhynchosporium secalis interaction: Newly identified QTL may represent already known resistance genes. Theor. Appl. Genet. 118:113-122.

Wang, C. F., Huang, L. L., Zhang, H. C., Han, Q. M., Buchenauer, H., and Kang, Z. S. 2010. Cytochemical localization of reactive oxygen species $\mathrm{O}-2$ - and $\mathrm{H} 2 \mathrm{O} 2$ and peroxidase in the incompatible and compatible interaction of wheat-Puccinia striiformis f. sp. tritici. Physiol. Mol. Plant Pathol. 74:221-229.

Wang, L. J., Wang, Y. J., Wang, Z., Marcel, T. C., Niks, R. E., and Qi, X Q. 2010. The phenotypic expression of QTLs for partial resistance to barley leaf rust during plant development. Theor. Appl. Genet. 121:857864.

Waugh, R., Jannink, J. L., Muehlbauer, G. J., and Ramsay, L. 2009. The emergence of whole genome association scans in barley. Curr. Opin. Plant Biol. 12:218-222.

Wise, R. P., Moscou, M. J., Bogdanove, A. J., and Whitham, S.A. 2007. Transcript profiling in host-pathogen interactions. Annu. Rev. Phytopathol. 45:329-369.

Yun, S. J., Gyenis, L., Hayes, P. M., Matus, I., Smith, K. P., Steffenson, B. J., and Muehlbauer, G. J. 2005. Quantitative trait loci for multiple disease resistance in wild barley. Crop. Sci. 45:2563-2572

Zellerhoff, N., Himmelbach, A., Dong, W. B., Bieri, S., Schaffrath, U., and Schweizer, P. 2010. Nonhost resistance of barley to different fungal pathogens is associated with largely distinct, quantitative transcriptional responses. Plant Physiol. 152:2053-2066.

Zeng, L. R., Vega-Sanchez, M. E., Zhu, T., and Wang, G. L. 2006. Ubiquitination-mediated protein degradation and modification: An emerging theme in plant-microbe interactions. Cell Res. 16:413-426.

Zierold, U., Scholz, U., and Schweizer, P. 2005. Transcriptome analysis of mlo-mediated resistance in the epidermis of barley. Mol. Plant Pathol. 6:139-151.

Zimmermann, G., Baumlein, H., Mock, H. P., Himmelbach, A., and Schweizer, P. 2006. The multigene family encoding germin-like proteins of barley. Regulation and function in basal host resistance. Plant Physiol. 142:181-192.

Zipfel, C. 2009. Early molecular events in PAMP-triggered immunity. Curr. Opin. Plant Biol. 12:414-420.

\section{AUTHOR-RECOMMENDED INTERNET RESOURCES}

Graingenes database: wheat.pw.usda.gov/GG2

HarvEST database: www.harvest-web.org 